\title{
THE CORINI ACTIVE FAULT IN SOUTHWESTERN VIOTIA REGION, CENTRAL GREECE: SEGMENTATION, STRESS ANALYSIS AND EXTENSIONAL STRAIN PATTERNS
}

\author{
Ganas A. ${ }^{1}$, Spina V. ${ }^{2}$, Alexandropoulou N. ${ }^{1}$, Oikonomou A. ${ }^{1}$, and \\ Drakatos G. ${ }^{1}$
}
${ }^{1}$ Institute of Geodynamics, National Observatory of Athens, 11810 Athens, Greece aganas@gein.noa.gr

${ }^{2}$ Earth Sciences Dept, Univ. Camerino, V. Gentile III da Varano, Camerino (MC), Italy

\begin{abstract}
The Corini normal fault is an active structure of Quaternary age in Southwestern Viotia. This is a region of low finite strain, located between the Quaternary rifts of the Gulf of Corinth and the Gulf of Evia. The fault is segmented into several segments with an average strike of $N 58^{\circ} \mathrm{E}$ and dip direction to the SE. The architecture of the fault zone is characterized by a $15 \mathrm{~cm}$ thick gouge rock, observed along the fault plane on the footwall side. At several localities along strike we observed a well-defined basal strip of un-eroded fault plane that represents the width (uplift) of the last co-seismic slip. The width of the strip ranges $20-30 \mathrm{~cm}$. Slip inversion data show a mean orientation of sigma3 (least principal stress) as $N 328^{\circ} \mathrm{E}$ which implies similar kinematics with the active faults of the south coast of the Gulf of Corinth.
\end{abstract}

Key words: Strain, active faults, fault slip, stress, Corini.

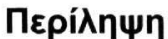

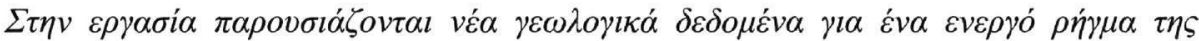

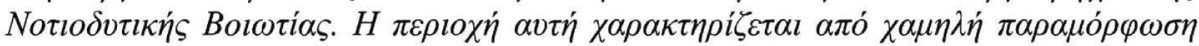

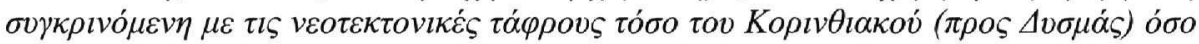

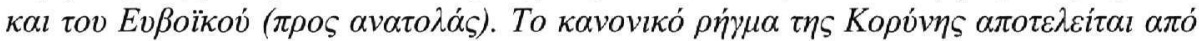

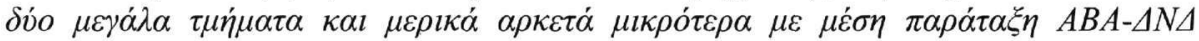

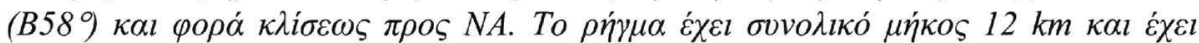

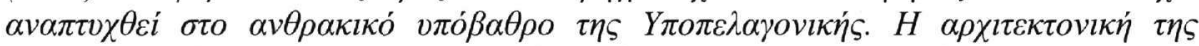

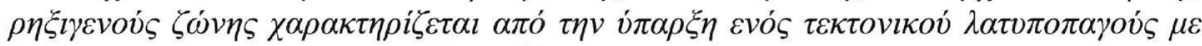

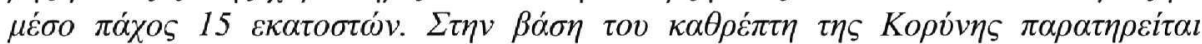

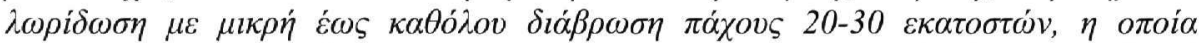

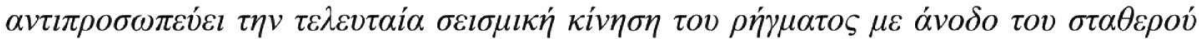

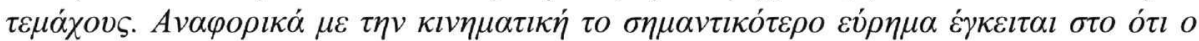

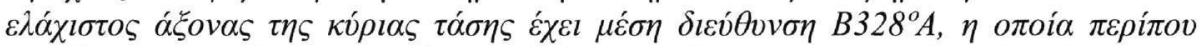

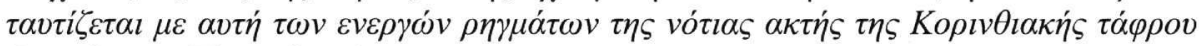

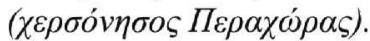

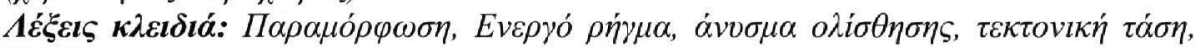

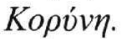




\section{Introduction}

Numerous structural and geodetic studies have shown that central Greece is a young, extensional province of the Aegean area and one of the most actively deforming in the world (Jackson et al. 1982, King et al. 1985, Roberts and Ganas 2000, Briole et al. 2001). Surface topography and geomorphology are clearly associated with seismic activity along large normal faults developed during the last 1-3 Ma (million years). Extension is mainly directed N-S with increasing rates to the west (Clarke et al. 1998). The main extensional features are a series of Plio-Pleistocene rifts such as the Gulf of Corinth and the Gulf of Evia (Fig. 1; Ganas and Papoulia 2000, Goldsworthy and Jackson 2001). The southern side of the Gulf of Corinth is bound by a series of major northdipping normal faults, forming a complex asymmetric half graben (Jackson et al. 1982, Roberts 1996, Morewood and Roberts 2001). There are E-W striking active normal faults with antithetic dip, i.e. to the south; however, they are visible at the northern edge of the Gulf. Two of these normal faults are the Kaparelli fault that ruptured in 1981 (Jackson et al. 1982) and the Corini fault in south-west Viotia. Our work presents new data on strain patterns along the Corini fault including sets of slip vector orientations and other geological observations along a 12-km stretch to the east of Corini village (Fig. 2). We also present detailed 1:5000 maps showing fault segmentation patterns and 32 morphological profiles that can be used a proxy to throw profiles across the fault. Similar data were also collected for the Erithres fault, a large normal fault to the east, including 1:5000 geological maps, stereonets from structural analysis etc. In this paper we focus on the Corini Fault and compare our results with the kinematics of active faults along the south coast.

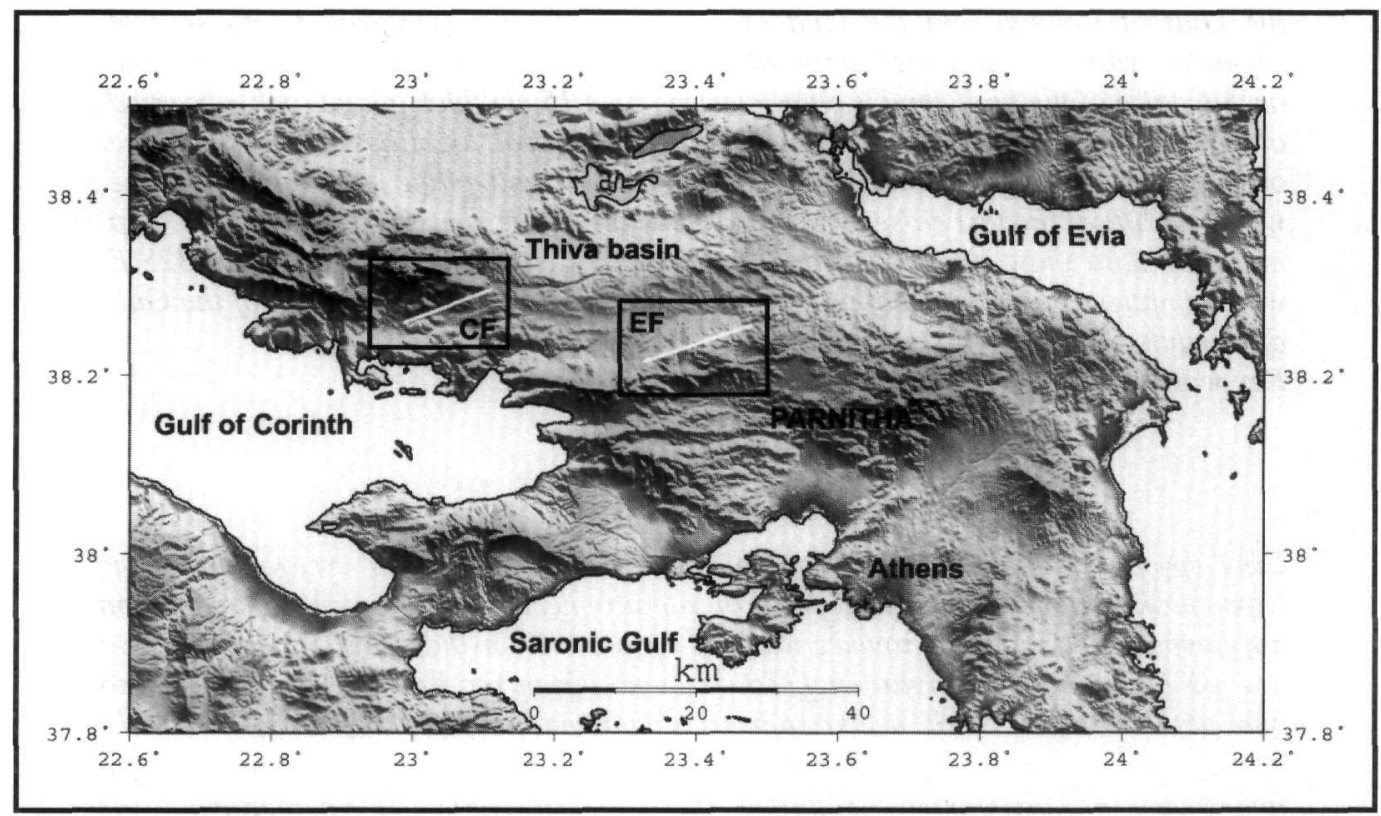

Figure 1 - Shaded relief map of Attica and Viotia regions in central Greece. Illumination is from the north-east. Black rectangles indicate locations of Corini Fault (CF) and Erithres Fault (EF), respectively. Area of rectangle CF is shown in Figure 2, below. Thin white lines indicate linear traces of active faults. Elevation data were provided by the SRTM mission

Our goal was to analyze structural data from active normal faults and to describe their architecture and the structural characteristics. This approach allowed us to constraint the orientation of the stress field and that to determine the direction of extension since Plio-Quaternary time in this sector of the central Greece. In detail, the results include a map of active faults in the area (Fig. 3), analysis of their lengths, cumulative slip (throw) estimates, analysis of dip angles and slip directions, and associated maximum earthquake magnitudes. Detailed mapping has examined the 
fault segmentation pattern, which is whether faults aligned along a particular direction form part of the same zone (a segment; e.g. Crone and Haller 1991) or are separate structures. In addition, lineation (striae) data from the main fault planes were collected at various localities. Data from smaller footwall faults were collected, as well. We also examine if the dominant fault-slip direction in our data set does not remain constant along strike, but varies systematically. Our findings can be compared to lineation data sets as suggested by Roberts and Ganas (2000). We will investigate if striations produced by ruptures exhibit converging patterns of slip towards the hangingwall, and how those patterns are distributed along the fault. For example, two lineation sets with different orientations implies rupture of different portions of the same fault segment during successive earthquakes (Roberts and Ganas 2000).
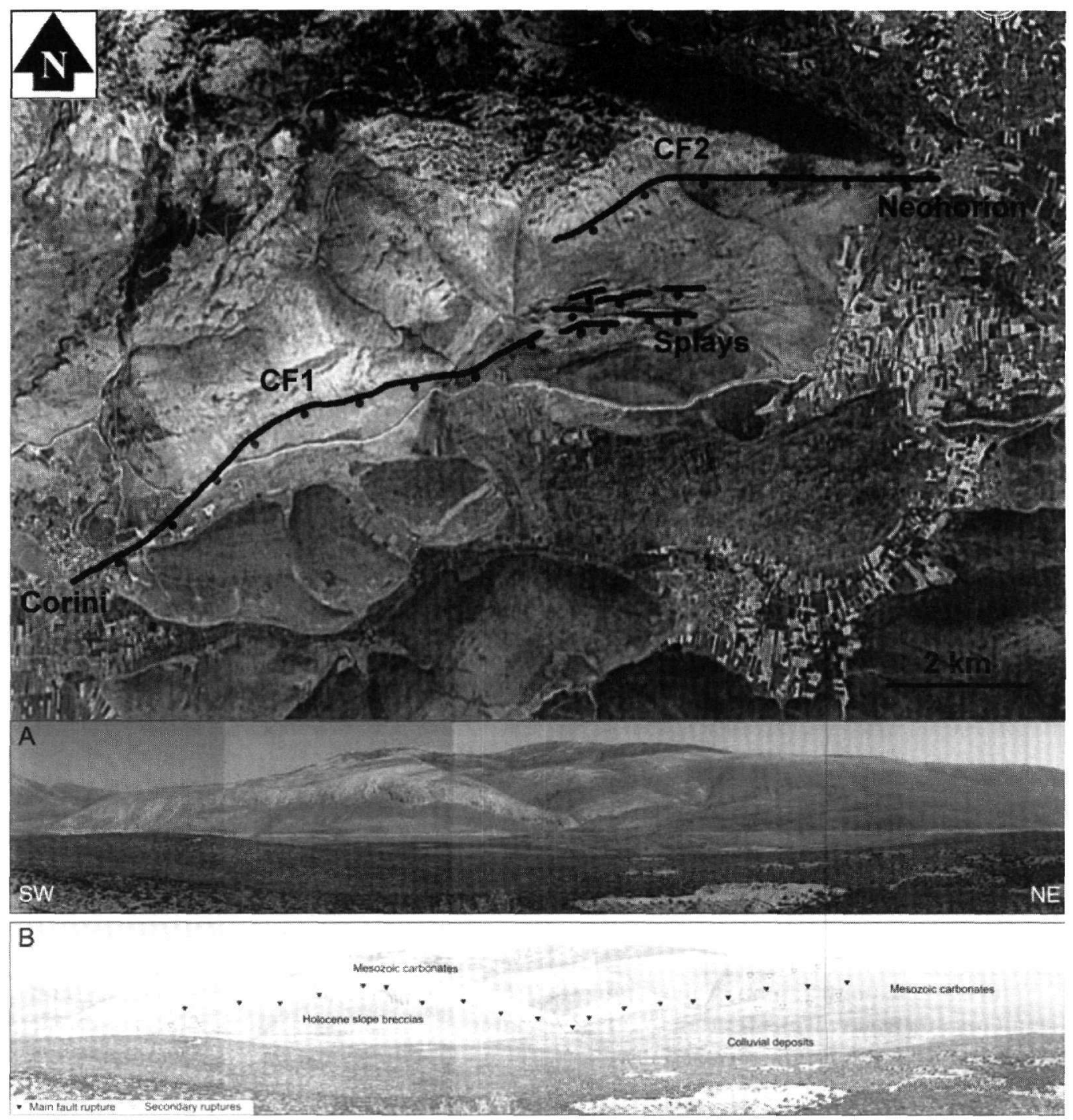

Figure 2 - Satellite image and corresponding field photograph of the Corini normal fault in south-west Viotia region, central Greece. Top: Landsat image with superimposed traces of active faults. Middle: Original picture, Bottom: main fault plane is indicated by a series of black triangles. Secondary planes are shown by the alignment of white triangles. The main rock types are also indicated. The highest altitude of the fault plane is approximately $480 \mathrm{~m}$.

View to the Northwest. Photograph taken 14 June 2006 


\section{Geological Setting}

The Corini Fault has developed at high angles to the dominant NW-SE structural trend of the Hellenides. The pre-rift rocks comprise mainly Mesozoic carbonates (limestone and dolomite; Fig. 2 ). We mapped the faults at high resolution scale $(\geq 1: 5000)$ and created a large data-set by collecting geo referenced structural surveys. The $12 \mathrm{~km}$ long Corini normal fault (CF) crops out along the southern slope of the Elikon Mountain (Figs 1, 2). The fault strikes roughly NE-SW, dips toward SE, and it is characterized by a segmented pattern (Fig. 3). The fault is marked by a rectilinear and fresh scarp, brings into contact Mesozoic rocks in the footwall, with reddish coarse grained colluvium and slope deposits of probably Holocene age, in the hanging wall. At the fault termination zones, near Corini and Neohorion villages, we observed in the hanging wall area pelites and reddish marls (syn-rift deposits) of Plio-Pleistocene age (Fig. 3). The architecture of the $\mathrm{CF}$ is characterized by two main fault segments; the western segment named here CF1 is shown in the field photograph of Figure 2. The geological map of this area shows that CF1 (Fig. 3), starts from the Corini village extending for almost $8 \mathrm{Km}$ to the east and it is characterized by fifteen (15), shorter fault segments showing both right and left stepping (Fig. 3). CF2 is $4 \mathrm{~km}$ long and terminates near the Neohorion village. CF2 was mapped at 1:50000 scale.

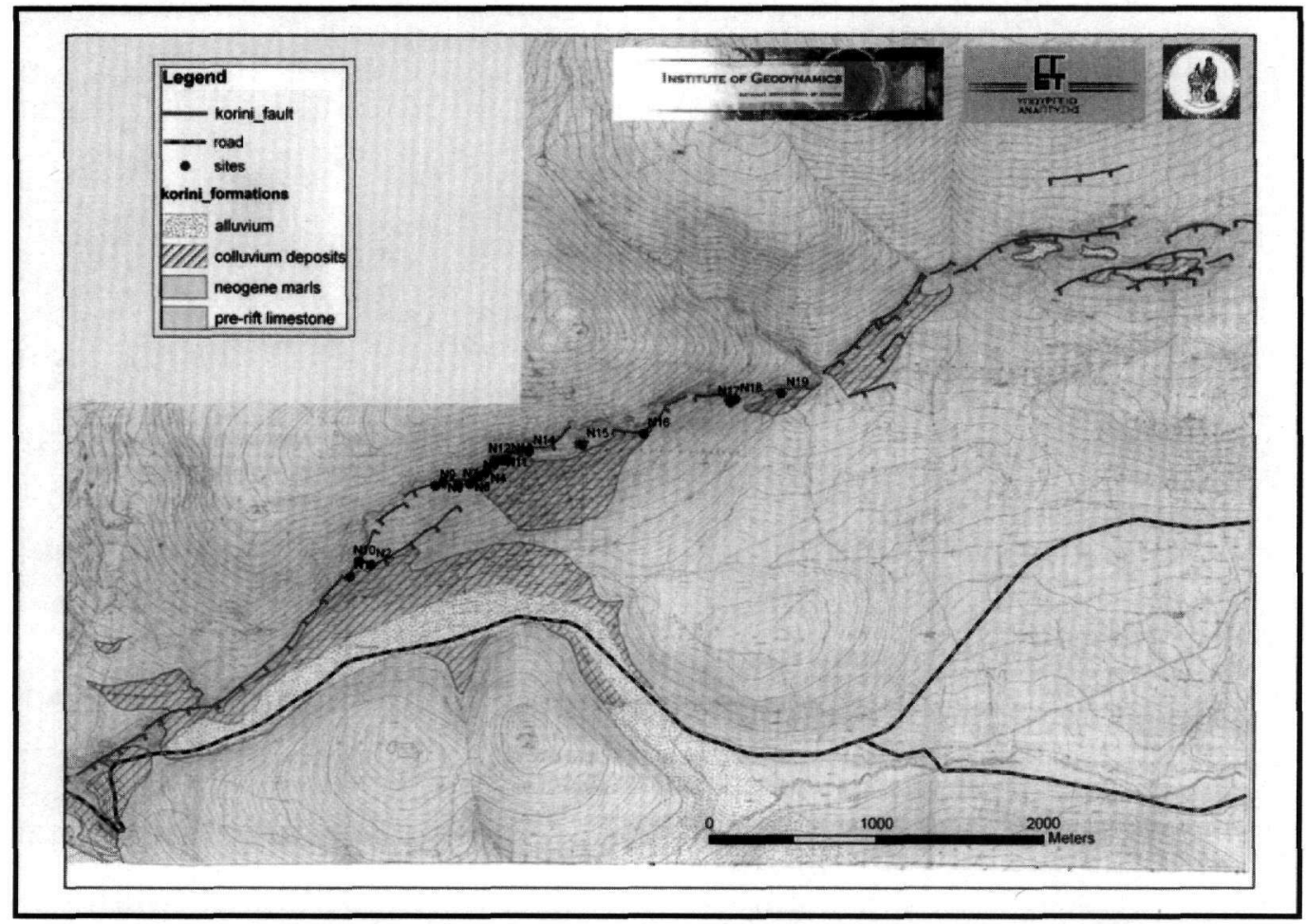

Figure 3 - Geological map of the segment CF1 of the Corini fault showing smaller fault segments and structural sites ( $\mathrm{N} 1$ to $\mathrm{N} 19)$. Location of $\mathrm{N}$ points was determined in the field with a hand-held GPS (accuracy $5 \mathrm{~m}$ ). Background topographic map has elevation interval of $4 \mathrm{~m}$

Near Corini village (west end), CF1 crops out at elevations $280 \mathrm{~m}$ to $480 \mathrm{~m}$. Here, it is characterized by a $3 \mathrm{~m}$ high fault scarp along which we observed an eroded fault plane in carbonate rocks with a basal strip along its base (Fig. 4c) and with associated a damage zone of almost 10-15 m. Also, reddish cemented and striated breccias of variable thickness were observed along the main fault plane (Fig. 4a). Further to the east, CF1 is well exposed along the main slope of Elikon Mountain (Fig. 2), from $400 \mathrm{~m}$ to $600 \mathrm{~m}$ of elevation, and towards its end it is characterized by overlapping fault strands that depict a complex array (Fig. 3 east of point N19). 
We interpret this fault pattern as an "isolated-splay" structure because small normal faults are seen to cluster at the termination of CF1 (Fig. 3) without either an "anastomosing" or a "branching" relationship to it. Between points N9 and N19 CF1 displays an impressive feature with a morphological break up to $31 \mathrm{~m}$; also, 1-2 cm long crystals of calcite were occasionally observed along main fault plane (Fig. 4b). In addition, secondary ruptures, both in the hanging wall and in the foot wall of the CF1, were mapped. The architecture of the fault zone along the entire CF1 is characterized by a $15 \mathrm{~cm}$ thick gouge rock, observed along the fault plane on the footwall side. At several localities along strike of CF we observed a well-defined basal strip of un-eroded fault plane that represents the extent (uplift) of the last co-seismic slip (Fig. 4e). The width of the strip is about $20-30 \mathrm{~cm}$.
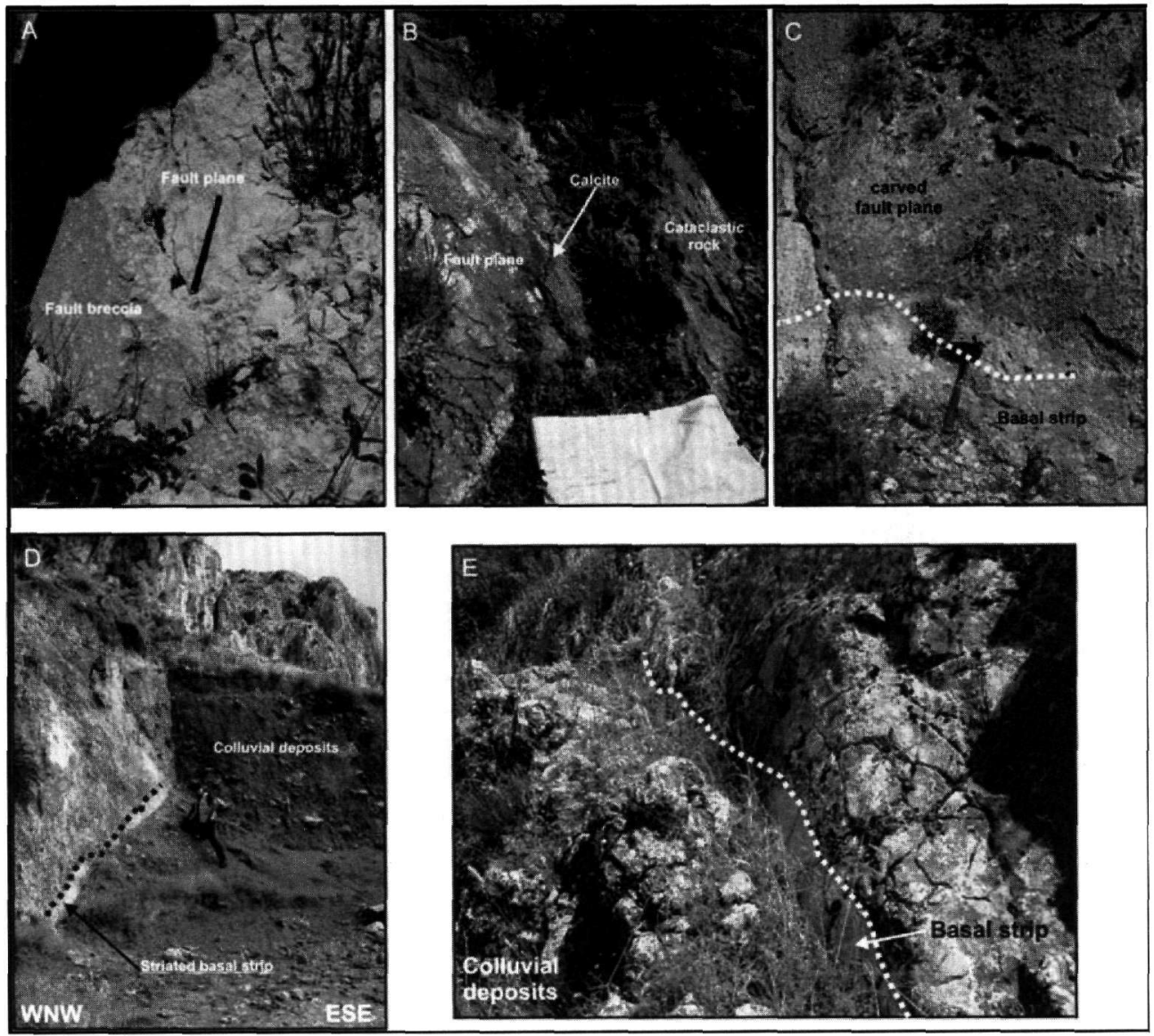

Figure 4 - Field photographs of the Corini active fault showing a) detail of fault plane in contact with fault breccia b) detail of fault plane with calcite crystals c) $30-\mathrm{cm}$ basal strip of equal width indicating last co-seismic slip (hammer for scale) d) Fault plane contact with colluvium (site $\mathrm{N} 1$; view to the east) and e) detail of fault surface with basal strip indicated by arrow. All photographs were taken during June 2006

\section{Analysis of Structural Data}

Along the CF1 segment we performed a systematic surveying in order to collect structural data (e.g. fault orientation, fault striae, and displacement-length profiles). To obtain accurate data concerning the rupture surface, each structural site was marked in the field with a hand-held GPS and it was geo-referenced to the UTM projection with GIS software. The GIS base map originated from a mosaic of 1:5000 maps of the Greek Army that was georeferenced to the UTM projection 


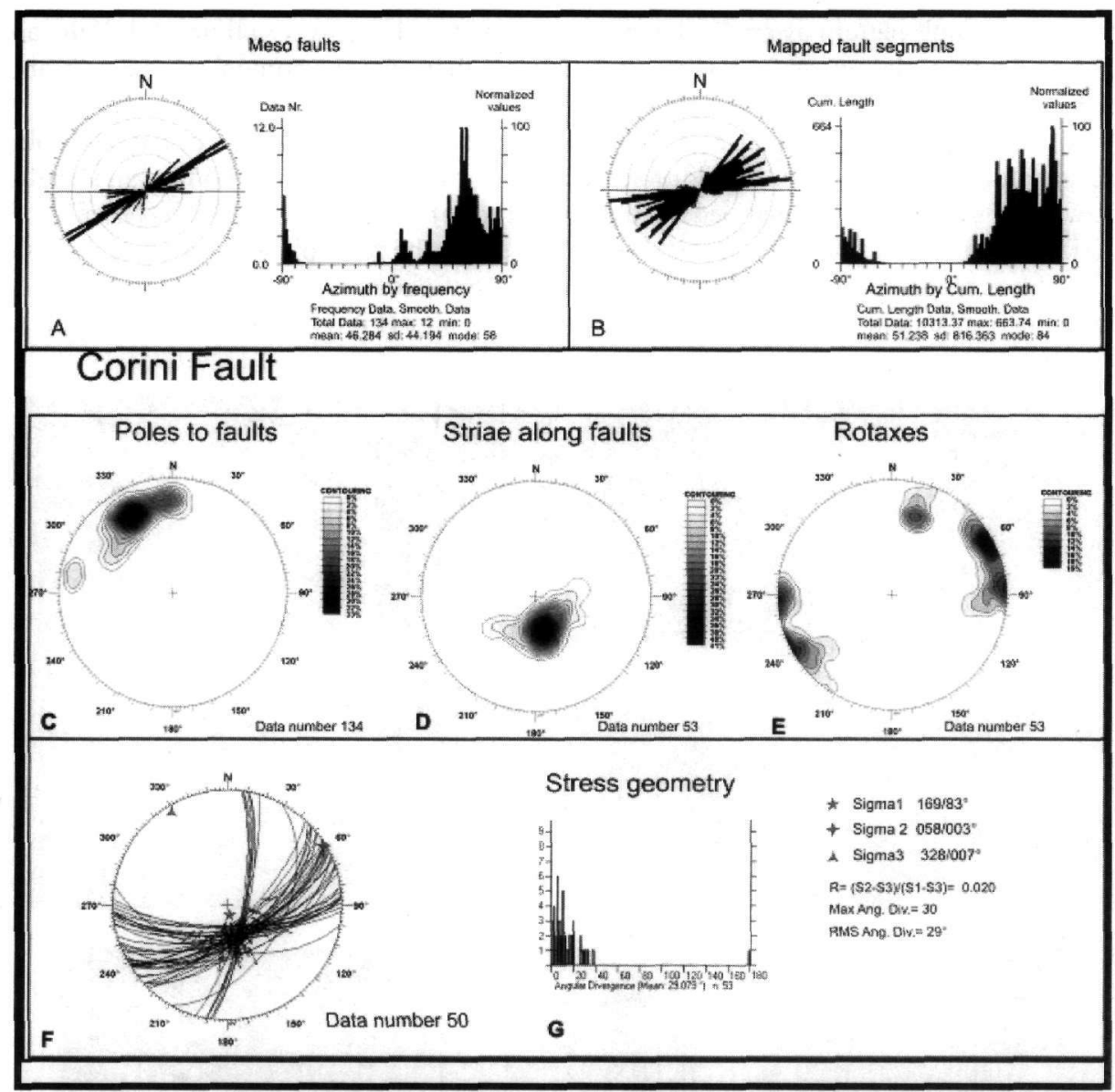

Figure 5 - Structural analysis of the Corini Fault. The data comprise 134 measurements of strike and dip angle and 53 measurements of rake angle on the fault plane. North is marked by "N". A) Data portrayed on rose diagrams: Strike of fault planes and histogram of fault

plane orientations (azimuth). B) Histogram of fault segment length vs. fault segment azimuth showing that NE segments are more important in accumulating fault length. C) D) E) Data are portrayed on lower hemisphere equal-area projections (Stereonets). Stereonets portray all data as contoured poles to the strike and dip of planes and trend and plunge of lines. The percent data at the contoured point maximum is indicated to the right of each stereonet. The number of points in the data sets is indicated in the lower right of each diagram. F) \& G) Paleostress analysis. Stress axis terminology is as follows: sigma 1 denotes trend and plunge of maximum principal stress, sigma 2 of intermediate stress and sigma 3 of least stress, respectively

using ARC GIS v. 9.1. Fault data are plotted on rose diagrams (Figs 5a, 5b) and stereonets (Figs 5c to f) using the Structural Data Integrated System Analyzer software (DAISY 2.19) by Salvini (2000). The DAISY software uses a Gaussian curve-fitting routine for determining peaks in directional data (Salvini et al. 1999) that was first described by Wise et al. (1985). This statistical method includes three different and progressive steps: Histogram Analysis, Multiple Gaussian Analysis and Spectral Analysis to filter and show the distribution and frequency data of the selected parameters. In particular, the Transect Analysis allowed us to highlight strike distribution, dip and rake variations of fault planes along a well oriented transect parallel to the fault (Fig. 6). Considering the scale which we collected data, we chose to show the processing of the Multiple Gaussian analysis. The structural data collected were then used to discuss the geometry of the 
fault-related stress ellipsoid (Fig. $5 \mathrm{~g}$ ) and the direction of extension associated to the studied faults. The mean strike of fault planes was found $\mathrm{N} 46^{\circ} \mathrm{E}$ (Fig. 5a), the standard deviation $44.1^{\circ}$ and the mode $\mathrm{N} 58^{\circ} \mathrm{E}$. In Figure $5 \mathrm{c}, 5 \mathrm{~d}$ and $5 \mathrm{f}$ we show contour diagrams of poles to fault planes, rake angle of striae (slickensides) along fault planes and rotational axes. The latter represent structural lineations on fault planes orthogonal to the slip vector (corresponding to the direction of the maximum shear stress). Their distribution indicates the intermediate axes of the stress ellipsoid $(\sigma 2)$. The contour diagrams give the statistical distribution of percentage of values in respect to all collected data. For poles of fault planes the best fit is $332 / 24^{\circ}$ (dip direction and inclination), for striations, the best fit is $165 / 68^{\circ}$ (trend and plunge) and for rotaxes, the best fit is $60 / 6^{\circ}$ (trend and plunge).

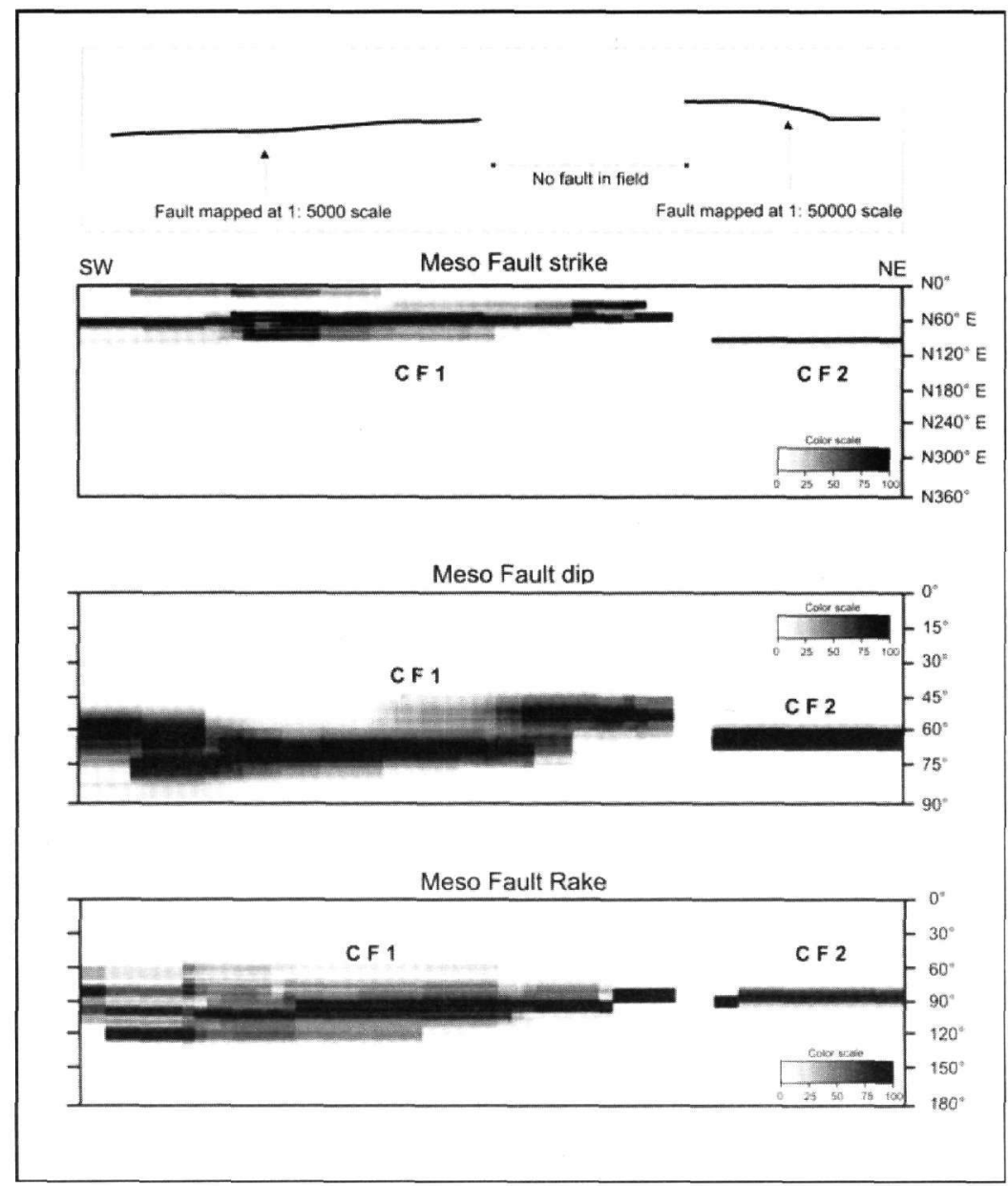

Figure 6 - Transect Analysis of the Corini Fault. Line brightness is proportional to the volume of data collected in the field. It can be seen that segment $\mathrm{CF} 2$ strikes $\mathrm{N}^{\circ}{ }^{\circ} \mathrm{E}$, dips $60^{\circ}-70^{\circ}$ south and rake is almost $90^{\circ}$, i.e. motion is pure dip-slip. However, the rake along the segment CF1 is mostly $>90^{\circ}$ indicating right-lateral movement

The analysis of the slip inversion (Fig. 5G) showed that the stress field is extensional with sigma 3 $(\sigma 3)$ oriented $\mathrm{N} 328^{\circ} \mathrm{E}$. The maximum angular divergence between the predicted and the actual slip direction is $30^{\circ}$ because of fault segmentation along strike. The sigma 3 value from Corini compares well with the mean extension direction $\left(\mathrm{N} 320^{\circ} \mathrm{E}-\mathrm{N} 340^{\circ} \mathrm{E}\right)$ of the $\mathrm{T}$-axis of the 1981 earthquakes (Taymaz et al. 1991), as well as with the mean extension direction defined by the slip vector data of the 1981 surface ruptures $\left(\mathrm{N} 350^{\circ} \mathrm{E}\right.$; Jackson et al. 1982). This result implies that 
fault kinematics is similar on either side of the Gulf of Corinth. On the contrary fault slip data from Ganas et al. (2004) and Roberts and Ganas (2000) show that immediately to the north-east, east and south-east of the Corini Fault area the sigma 3 orientation changes to $\mathrm{N} 7^{\circ}-\mathrm{N} 14^{\circ} \mathrm{E}$. In addition, the transect analysis method shows that the spatial variation of fault slip vector is constant for segment CF2 but not for segment CF1 (Fig. 6) where it is seen that the oblique-slip component of fault motion is mostly right lateral. A possible explanation for this behaviour is that fault slip patterns have not been developed due to the young age of segmentation or that the western end of the fault is part of a larger structure (a relay ramp) where earthquake ruptures from neighbouring segments can propagate.

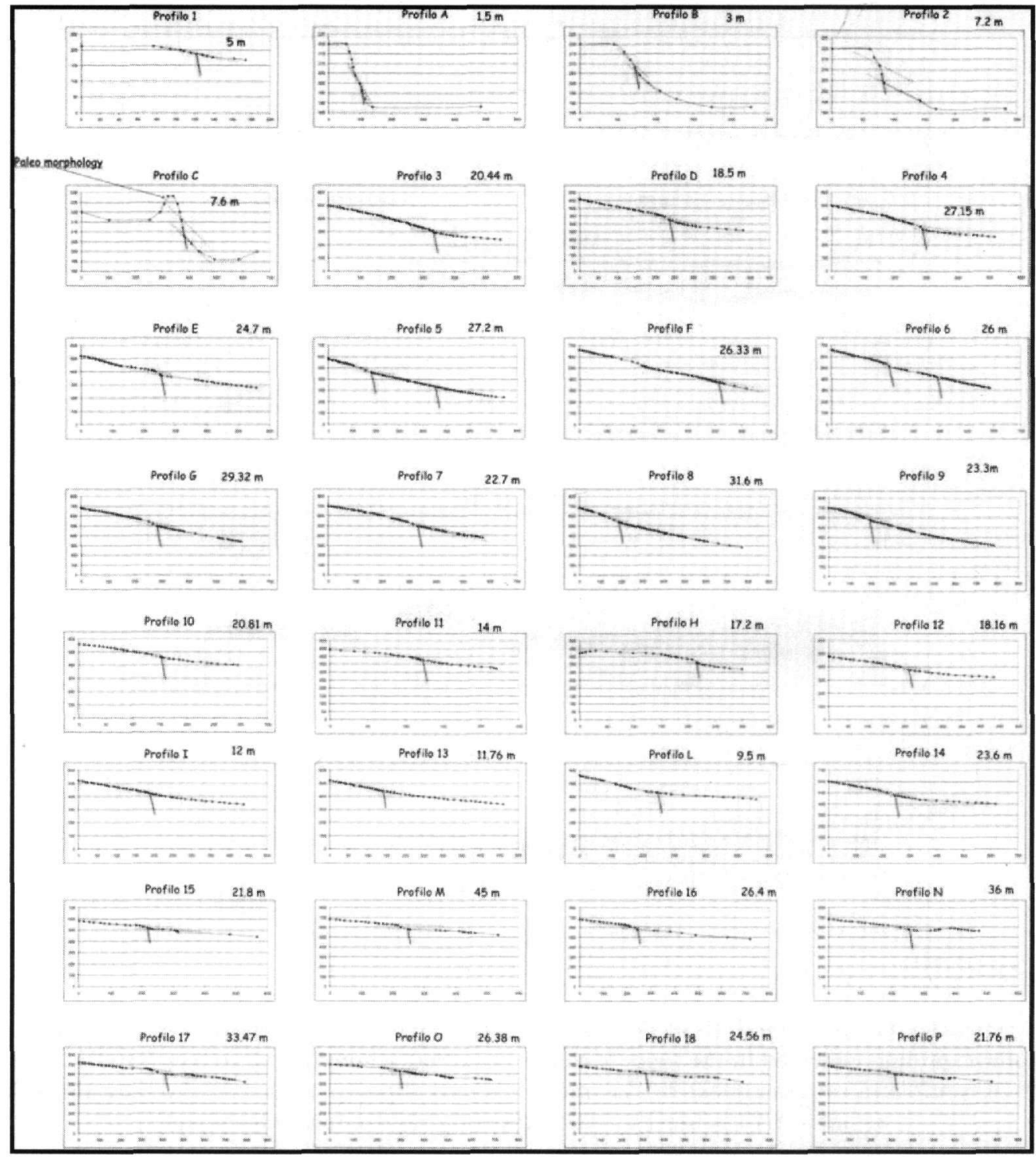

Figure 7 - Topographic profiles across the Corini Fault (segment CF1). All profiles are oriented approximately NNW-SSE. Thin, near vertical line indicates location of fault. The morphological offset equals the height difference between top scarp and bottom scarp and ranges between 5-45 m. Presumable this value represents fault throw since the end of the last glaciation (18 Ka; Roberts and Michetti 2004) 

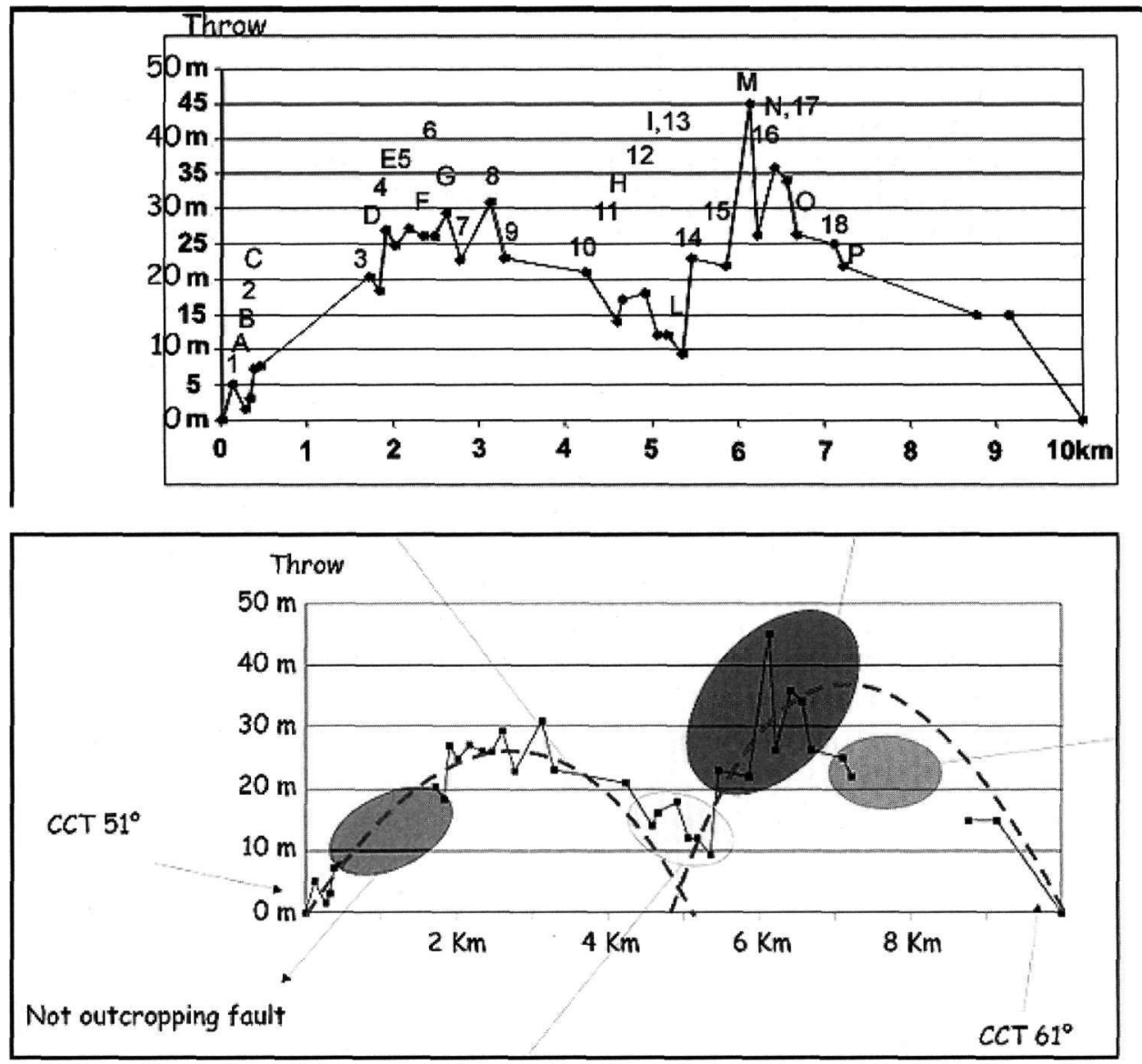

Figure 8 - (Top) Displacement-Length diagrams for the Corini Fault - segment CF1. Data points (black boxes with labels) originate from morphological profiles of Figure 7. We suggest that morphological offset is representative of fault displacement because of similar bedrock lithology and fault dip direction along strike. We observe that the profile does not fit the ideal, elliptical shape but shows two maxima at $2-3 \mathrm{~km}$ and $6-7 \mathrm{~km}$, respectively.

(Bottom) Sketch for interpretation of top graph. The profile can be split into two parts, each one with almost similar bell-shaped profile. The area between 4 and $6 \mathrm{~km}$ shows low throw values which suggest a linkage of two CF1 proto-segments

We could not collect any reliable geological data on throws along the Corini Fault. We can infer that throws are generally small because the NE-SW basin that develops in the hangingwall shows no evidence for thick syn-rift (Fig. 3). The main syn-rift lithology is colluvium and alluvium with minor occurrence of marl and pelite. It is therefore, reasonable to suggest that $\mathrm{CF}$ is a young structure perhaps not older that $1000000(1 \mathrm{Ma})$ years. One method to study throw variations along strike (throw is the vertical component of the displacement vector) is to draw vertical crosssections across the main fault plane and measure the morphological offset of the scarp (Fig. 7). The morphological offset we measure along strike can be used as a proxy for geological throw because the bedrock lithology is the same (Mesozoic carbonate) and dip-direction is constant (to the SE). The offset ranges from 5-45 $\mathrm{m}$ and shows two maxima along strike (Fig. 8). A possible explanation for this shape asymmetry is that CF1 grew because of linkage of two proto-segments. This is an important observation because in the field we were not able to see this. Also, the 1:50000 topographic map shows that along the Corini fault two large segments are clearly visible. The structural analysis (Figs 5,6) also supports this interpretation. Strikes of fault planes for CF1 
cluster around $\mathrm{N} 60^{\circ} \mathrm{E}$ but for $\mathrm{CF} 2$ are close to $\mathrm{N} 100^{\circ} \mathrm{E}$. Rake of fault planes along $\mathrm{CF} 1$ is most right-lateral but for CF2 is almost $90^{\circ}$ (dip-slip). The segment boundary area between CF1 and CF2 is to the north of CF1 (Figs 2, 3) where fault plane occurrence is lost. If we assume a late Pleistocene age for the reddish breccias occurring along the fault plane (100000 - 20000 years) we can estimate a mean slip rate for this fault. The reddish breccias have been associated with postglacial weathering of slopes (see Roberts and Michetti 2004). This rough estimate provides mean slip rates in the order $0.2-1 \mathrm{~mm} / \mathrm{yr}$.

\section{Discussion - Conclusions}

a) The Corini normal fault shows evidence of recent tectonic activity such as fresh fault planes, axial drainage, linear mountain fronts etc., typical for the Aegean region. It borders an impressive mountain range constituted by Mesozoic carbonates. Geological data on slip vectors from Corini can be used to measure the crustal extension direction because in previous studies Hancock and Barka (1987) and Stewart and Hancock (1988, 1990, 1991) have showed that recently activated or freshly exhumed normal fault planes exhibit kinematic indicators ranging from metre-scale corrugations and gutters to centimetre-scale frictional wear striae. Also, Roberts (1996) and Roberts and Ganas (2000) made use of those indicators to model the non-characteristic growth of normal faults inside juvenile rifts such as those in central Greece.

b) The architecture of the $\mathrm{CF}$ is characterized by two main fault segments; the western segment starts from the Corini village extending for almost $8 \mathrm{Km}$ to the east and it is characterized by shorter fault segments (500-1000 m long) showing both right and left stepping (Fig. 3). In addition, the Late Quaternary displacement - length profile (Fig. 8) can be split into two parts, each one with almost similar bell-shaped profile. The area between 4 and $6 \mathrm{~km}$ shows low throw values which suggest a linkage of two Corini-fault protosegments, now comprising CF1.

c) At several localities along strike of CF1 we observed a well-defined, erosion-free basal strip on the fault plane that represents the extent (uplift) of the last co-seismic slip. The width of the strip is $20-30 \mathrm{~cm}$ (Fig. 4). This amount is similar to basal stripes found along other normal faults in neighbouring rifts (Fig. 1; Lemeille 1977, Ganas et al. 1998, Ganas et al. 2004).

d) The dominant fault-slip direction in our data set does not remain constant along strike, but varies from right-lateral oblique-slip (CF1) to almost dip-slip (CF2). No left-lateral striations were found.

e) We can estimate the maximum earthquake from the Corini normal fault using the best established correlation relation which Wells and Coppersmith (1994) have determined for shallow-focus (crustal) continental interplate or intraplate earthquakes on the basis of a rather comprehensive data base of historical events: $\mathrm{Mw}=(1.16 \pm 0.07) \log (\mathrm{SRL})+(5.08$ \pm 0.10 ). For $\mathrm{SRL}=12 \mathrm{~km}$ we estimate $6.2<\mathrm{Mw}<6.5$.

f) The historical seismicity of this fault is unknown. No association can be established with the $M>6.0$, large earthquakes of the $19^{\text {th }}$ Century near the town of Thiva (18.8.1853 and 23.5.1893; Ambraseys and Jackson 1990).

g) The analysis of the slip inversion data from CF showed that the stress field is extensional with sigma $3(\sigma 3)$ oriented $\mathrm{N} 328^{\circ} \mathrm{E}$. This value compares well with the mean extension direction of the T-axis of the 1981 earthquakes, as well as with the mean extension direction defined by the slip vector data of the 1981 surface ruptures. This result implies that fault kinematics are similar on either side of the Gulf of Corinth 


\section{Acknowledgments}

This work was funded by the PREVIEW IP Project (FP6), the General Secretariat for R\&T (Greece) and the National Observatory of Athens. F. Salvini advised us on using the DAISY software for data elaboration. C. Tsimi helped with the use of ARC GIS. Figure 1 was made by the use of GMT software. Satellite image of Figure 2 was obtained from Google Earth ${ }^{\mathrm{TM}}$. We thank one anonymous reviewer for comments and Prof Hara Drinia for editorial assistance. We also thank Spiros Pavlides, Emanuele Tondi for discussions and George Stavrakakis for his support.

\section{References}

Ambraseys, N.N., and Jackson, J.A., 1990. Seismicity and associated strain of central Greece between 1890 and 1988, Geophysical Journal International, 101(3), 663-708.

Briole, P., Rigo, A., Lyon-Caen, H., et al., 2000. Active deformation of the Corinth rift, Greece: Results from repeated Global Positioning System surveys between 1990 and 1995, Journal of Geophysical Research, 105(B11), 25605-25625.

Clarke, P.J., Davies, R.R., England, P.C., et al., 1998. Crustal strain in central Greece from repeated GPS measurements in the interval 1989-1997, Geophysical Journal International, $135(1), 195-214$.

Crone, A., and Haller, KM., 1991. Segmentation and the coseismic behavior of Basin and Range normal faults; examples from east-central Idaho and southwestern Montana, U.S.A., Journal of Structural Geology, 13, 151-164.

Ganas, A., Roberts, G.P., and Memou, Tz., 1998. Segment boundaries, the 1894 ruptures and strain patterns along the Atalanti Fault, Central Greece, Journal of Geodynamics, 26, 2-4, $461-486$.

Ganas, A, and Papoulia, I., 2000. High-resolution, digital mapping of the seismic hazard within the Gulf of Evia Rift, Central Greece using normal fault segments as line sources, Natural Hazards, 22 (3), 203-223.

Ganas, A., Pavlides, S.B., Sboras, S., Valkaniotis, S., Papaioannou, S., Alexandris, A.G., Plessa, A., and Papadopoulos, G.A., 2004. Active fault geometry and kinematics in Parnitha Mountain, Attica. Greece, J. Structural Geology, 26, 2103-2118.

Goldsworthy, M, and Jackson, J., 2001. Migration of activity within normal fault systems: examples from the Quaternary of mainland Greece, Journal of Structural Geology, 23 (23), 489-506.

Hancock, P.L., and Barka, A.A., 1987. Kinematic indicators on active normal faults in western Turkey, Journal of Structural Geology, 9, 573-584.

Jackson, J.A., Gagnepain, J., et al., 1982, Seismicity, normal faulting and the geomorphological development of the Gulf of Corinth (Greece): the Corinth earthquakes of February and March 1981, Earth \& Planet. Sc. Let., 57, 377- 397.

King, GCP, Ouyang, Z.X., Papadimitriou, P., et al., 1985. The evolution of the Gulf of Corinth (Greece) - an aftershock study of the 1981 earthquakes, Geophysical J. Royal S., 80 (3), 677.

Lemeille, F., 1977. Etudes rnicrotectoniques en Grèce Centrale Nord-Orientale (Eubèe Centrale, Attique, Bèotie, Locride), Thèse 3eme cycle, Univ. Paris XI, 173pp.

Morewood, N.C., and Roberts, G.P., 2001. Comparison of surface slip and focal mechanism slip data along normal faults: an example from the eastern Gulf of Corinth, Greece, Journal of Structural Geology, 23 (2-3), 473-487. 
Roberts, GP, 1996. Non-characteristic normal faulting surface ruptures from the Gulf of Corinth, Greece, Journal of Geophysical Research, 101 (B11), 25255-25267.

Roberts, G.P., and Ganas, A., 2000. Fault-slip directions in central and southern Greece measured from striated and corrugated fault planes: Comparison with focal mechanism and geodetic data, Journal of Geophysical Research, 105 (B10), 23443-23462.

Roberts, G.P., and Michetti, A.M., 2004. Spatial and temporal variations in growth rates along active normal fault Systems: an example from Lazio-Abruzzo, central Italy, Journal of Structural Geology, 26, 339-376.

Salvini, F., 2000. Structural Data Integrated System Analyzer software (DAISY 2.19), Dipartimento di Scienze Geologiche, Universita degli Studi di "Roma Tre", Rome, Italy.

Salvini, F., Billi, A., and Wise, D.U., 1999. Strike-slip fault propagation cleavage in carbonate rocks: the Mattinata Fault Zone, Southern Apennines, Italy, Journal of Structural Geology, 21, 1731-1749.

Stewart, I.S., and Hancock, P.L., 1988. Normal fault zone evolution and fault scarp degradation in the Aegean region, Basin Research, 1, 139-153.

Stewart, I.S., and Hancock, P.L., 1990. Brecciation and fracturing within neotectonic normal fault zones in the Aegean region. In R.J. Knipe and E.H. Rutter (eds), Deformation Mechanisms, Rheology and Tectonics, Geological Society Special Publication 54, 105-110pp.

Stewart, I.S., and Hancock, P.L., 1991. Scales of structural heterogeneity within neotectonic normal fault zones in the Aegean region. In P.L. Hancock, R.S. Yeats and D.J. Sanderson (eds), Characteristics of Active Faults, Journal of Structural Geology, 13, 191-204pp.

Taymaz, T, Jackson, J.A., and McKenzie, D.P., 1991. Active tectonics of the north and central Aegean Sea, Geophysical Journal International, 106, 433-490.

Wells, D.L., and Coppersmith, K.J., 1994. New empirical relationships among magnitude, rupture length, rupture width, rupture are, and surface displacement, Bull. Seismol. Soc. Am., 84, 974-1002.

Wise, D.U., Funiciello, R., Parotto, M., and Salvini, F., 1985, Topographic lineament swarms: Clues to their origin from domain analysis of Italy, Geological Society of America Bulletin, 96, 952-967. 